ISSN 0258-7122

Bangladesh J. Agril. Res. 36(2) : 241-246, June 2011

\title{
STUDY ON THE CROSS COMPATIBILITY OF SOME LEMON GENOTYPES (Citrus limon L.)
}

\author{
M. I. $\operatorname{HOSSAIN}^{1}$ AND M. G. RABBANI ${ }^{2}$
}

\begin{abstract}
An investigation was carried out at the Department of Horticulture, Bangladesh Agricultural University, Mymensingh to examine compatible relationship among the available lemon genotypes. Seven selected genotypes of lemon were used for hybridization. Crossings were performed following diallel fashion. The results revealed that the lower percentage of fruit setting as well as seed setting in some cross combinations noticed the existence of incompatibility among the selected genotypes. The percentages of fruit setting and seed setting were higher in the cross-pollination than in the self- pollination, which was an indication of self-incompatibility. To achieve seedless fruit setting, self-incompatibility may be used successfully.
\end{abstract}

Keywords: Cross compatibility, lemon genotypes.

\section{Introduction}

Self and cross incompatibility of a crop is a major constraint in hybridization programme. High cross compatibility of the chosen parents along with other desirable horticultural traits accelerates success of any controlled hybridization programme. Incompatibility may exist among genotypes, it is necessary to find out the compatible relationship of the selected genotypes before attempting any inter-varietal hybridization.

Incompatibility is a serious problem in Citrus breeding. A series of limitations, such as nucellar polyembryony (apomixis), heterozygocity, self and crossincompatibility and long juvenility have made Citrus breeding through conventional methods a difficult task (Soost and Cameron, 1975). Barrett (1985) stated that even if crosses of Citrus are compatible, the following problems or difficulties still exist: (1) sexual crosses are usually much more difficult to make, and if seed is obtained at all, the seed yield is often low and it may be non-viable; (2) if hybrids are obtained, the progenies ultimately available for selection are often a few in number due to lethality, abnormal recombinants or poor field survival; (3) the survival hybrids may not flower, may have very long juvenile periods or may be completely or partially ovule or pollen sterile; (4) undesirable traits may be integrated in Citrus. However, this investigation was attempted to detect compatible relationship among the lemon genotypes for improvement of the crop.

\footnotetext{
${ }^{1}$ Associate Professor, Dept. of Horticulture \& Postharvest Technology, Shere-Bangla Agricultural University (SAU), Dhaka, ${ }^{2}$ Professor, Dept. of Horticulture, Bangladesh Agricultural University (BAU), Mymensingh, Bangladesh.
} 


\section{Materials and Method}

The investigation was conducted at the project field entitled "Collection, Evaluation, Conservation and Utilization of Land races and Wild relatives of some Important Vegetables and Fruits of Bangladesh (CVFB)", Department of Horticulture, Bangladesh Agricultural University, Mymensingh during the period from December 2006 to July 2007.

Plant materials: In a hybridization programme, to combine important traits of germplasm, seven genotypes of lemon were selected as parents based on their field performances. Parent $\mathrm{P}_{1}(\mathrm{CL} \mathrm{02})$ was selected for higher percentage of fruit set and higher yield, parent $\mathrm{P}_{2}$ (CL 03) for higher number of fruits per plant and higher yield, parent $\mathrm{P}_{3}$ (CL 07) for lower rind thickness and seedlesness, parent $\mathrm{P}_{4}$ (CL 18) for higher percentage of fruit set, higher number of fruits per plant and higher yield, parent $\mathrm{P}_{5}(\mathrm{CL} 24)$ for higher ascorbic acid content and seedlessness, parent $\mathrm{P}_{6}(\mathrm{CL} 33)$ and $\mathrm{P}_{3}$ (CL 24) for lower rind thickness and lower seed content (Table 1). The floral morphology of seven selected parents is also shown in Table 2. The crosses were performed following diallel crossing method without reciprocal.

Table 1. Variability of 7 inbred lines used as parents.

\begin{tabular}{|c|c|c|c|c|c|c|c|c|}
\hline Code & Genotypes & $\begin{array}{c}\% \text { Fruit } \\
\text { set }\end{array}$ & $\begin{array}{l}\text { No.of } \\
\text { fruits/ } \\
\text { plant }\end{array}$ & Yield & $\begin{array}{c}\text { Rind } \\
\text { thickness }\end{array}$ & $\begin{array}{c}\text { Juice } \\
\text { content }\end{array}$ & Vit. C & $\begin{array}{c}\text { Seeds/ } \\
\text { fruit }\end{array}$ \\
\hline $\mathrm{P}_{1}$ & CL 02 & High & Medium & High & High & Low & Medium & High \\
\hline $\mathrm{P}_{2}$ & CL 03 & Low & High & High & Low & Medium & High & Medium \\
\hline $\mathrm{P}_{3}$ & CL 07 & Medium & Low & Medium & Low & High & Medium & Seedless \\
\hline $\mathrm{P}_{4}$ & CL 18 & High & High & High & Medium & Medium & Medium & Medium \\
\hline $\mathrm{P}_{5}$ & CL 24 & Medium & Medium & Medium & Medium & Medium & High & Seedless \\
\hline $\mathrm{P}_{6}$ & CL 33 & Medium & Low & Medium & Low & Medium & Low & Low \\
\hline $\mathrm{P}_{7}$ & CL 34 & Low & Low & Low & Low & Medium & Medium & Low \\
\hline
\end{tabular}

Table 2. Floral morphology of 7 inbred lines used as parents.

\begin{tabular}{l|l|l|l|l|l|l}
\hline Code & Genotypes & $\begin{array}{c}\text { Position of } \\
\text { flower }\end{array}$ & $\begin{array}{c}\text { Colour of } \\
\text { flower bud }\end{array}$ & $\begin{array}{c}\text { Clour of } \\
\text { open } \\
\text { flower }\end{array}$ & $\begin{array}{c}\text { Length of } \\
\text { pedicel } \\
(\mathrm{mm})\end{array}$ & $\begin{array}{c}\text { Length of } \\
\text { bud }(\mathrm{cm})\end{array}$ \\
\hline $\mathrm{P}_{1}$ & CL 02 & Axillary & Reddish white & White & 3.06 & 3.14 \\
$\mathrm{P}_{2}$ & CL 03 & Axillary & Reddish white & White & 2.74 & 2.93 \\
$\mathrm{P}_{3}$ & CL 07 & Axillary & Reddish white & White & 2.61 & 2.72 \\
$\mathrm{P}_{4}$ & CL 18 & Axillary & white & Creamy & 3.05 & 2.93 \\
$\mathrm{P}_{5}$ & CL 24 & Axillary & Reddish white & White & 2.58 & 2.84 \\
$\mathrm{P}_{6}$ & CL 33 & Axillary & Greenish white & White & 2.69 & 3.17 \\
$\mathrm{P}_{7}$ & CL 34 & Axillary & Greenish white & White & 1.94 & 2.54 \\
\hline
\end{tabular}


Table 2. Cont'd.

\begin{tabular}{l|l|l|l|l|l}
\hline \multicolumn{1}{c|}{ Code } & Genotype & No. Stamen & $\begin{array}{c}\text { Length of } \\
\text { petal. }(\mathrm{cm})\end{array}$ & $\begin{array}{c}\text { Width of } \\
\text { petal }(\mathrm{cm})\end{array}$ & $\begin{array}{c}\text { Length of } \\
\text { anther }(\mathrm{mm})\end{array}$ \\
\hline $\mathrm{P}_{1}$ & CL 02 & 40.97 & 2.57 & 0.74 & 5.97 \\
$\mathrm{P}_{2}$ & CL 03 & 43.55 & 2.33 & 0.79 & 6.24 \\
$\mathrm{P}_{3}$ & CL 07 & 31.89 & 2.16 & 0.60 & 6.16 \\
$\mathrm{P}_{4}$ & CL 18 & 50.44 & 2.57 & 0.82 & 6.76 \\
$\mathrm{P}_{5}$ & CL 24 & 39.56 & 2.44 & 0.81 & 7.05 \\
$\mathrm{P}_{6}$ & CL 33 & 48.68 & 2.67 & 0.84 & 7.38 \\
$\mathrm{P}_{7}$ & CL 34 & 32.51 & 2.09 & 0.62 & 5.96 \\
\hline
\end{tabular}

Technique of crossing: For crossing, prospective female flowers of the mother parents and the male flowers of the pollen parents were bagged properly to avoid pollen contamination. Bagging was done at previous afternoon of anthesis. Emasculation of male parts of the flowers was done with forceps carefully to avoid any injury of the stigma in the preceding afternoon of anthesis of the flower. Then the emasculated flowers were covered with paper bag. Hand pollination was done between the selected parents in the following morning from 8:00 A.M. to 11:00 A.M. Between each of different combinations of parents 25 crosses were performed. Immediately after pollination, the pollinated flowers were again covered with bags. The crossed flowers were marked with tag and tagging was continued up to harvesting of fruit, developed from crossing.

Data recording: Fruits, developed from crosses were harvested at full mature stage and data of number of successful crosses and number of seed set were recorded.

\section{Results and Discussion}

From self-pollination, it was observed that the percentage of fruit setting ranged from 17 to $32 \%$ (Table 3 ). The highest percentage of fruit setting with selfpollination was observed in parent $\mathrm{P}_{2}(32 \%)$ followed by $\mathrm{P}_{4}(28 \%), \mathrm{P}_{6}(28 \%), \mathrm{P}_{1}$ (24\%), and $\mathrm{P}_{5}(24 \%)$. The lowest (17\%) was obtained in $\mathrm{P}_{3}$. On the other hand, the range of seed setting was 0 to 24 per fruit. The maximum seed setting was recorded in parent $\mathrm{P}_{2}$ (17-24) followed by $\mathrm{P}_{6}$ (15-22), $\mathrm{P}_{4}$ (15-19), $\mathrm{P}_{1}$ (13-18), and $\mathrm{P}_{7}$ (2-5). The minimum was in parent $\mathrm{P}_{5}(0-3)$. Parent $\mathrm{P}_{3}$ produced seedless fruit (Table 3). Nath (1999) reported that self-incompatibility led to seedless fruits. The results of this study indicated that parent $\mathrm{P}_{2}$ is more self-compatible than the others. The lower percentage of fruit setting as well as seed setting might be due to self-incompatibility. Vardi et al. (2000) observed self-incompatibility in mandarin. These findings are in agreement with present study. Luro et al. (2004) stated that self- incompatibility and sterility of genes produced seedlessness. Yamamoto and Tominaga (2002) reported seedlessness in Keraji (Citrus keraji) due to female sterility, self- incompatibility and parthenocarpy. 
Table 3. Success in selling of different lemon parents.

\begin{tabular}{l|l|l|l}
\hline \multicolumn{1}{c|}{ Parents/Genotypes } & $\begin{array}{c}\text { No. of success in } \\
\text { self- pollination }\end{array}$ & $\begin{array}{c}\text { Percentage of fruit } \\
\text { set }\end{array}$ & \multicolumn{1}{c}{ Seeds/fruit } \\
\hline $\mathrm{P}_{1}($ CL 02) & 6 & 24 & $13-18$ \\
$\mathrm{P}_{2}($ CL 03) & 8 & 32 & $17-24$ \\
$\mathrm{P}_{3}$ (CL 07) & 5 & 17 & 0 \\
$\mathrm{P}_{4}$ (CL18) & 7 & 28 & $15-19$ \\
$\mathrm{P}_{5}($ CL24) & 6 & 24 & $0-3$ \\
$\mathrm{P}_{6}$ (CL33) & 7 & 28 & $15-22$ \\
$\mathrm{P}_{7}$ (CL34) & 5 & 20 & $2-5$ \\
\hline
\end{tabular}

A wide range of variation in percentage of fruit setting and seed setting was observed from crosses among selected parents. In cross pollination, fruit setting varied from 20 to $56 \%$ (Table 4), which is greater than self pollination. Results indicated that cross-compatibility is higher than self-compatibility among the selected parents. Nath (1999) observed that fruit set and fruit retention percentages were higher in open and cross-pollination in Assam lemon, which support the present findings. The higher percentage of fruit setting was recorded in cross combinations $\mathrm{P}_{1} \times \mathrm{P}_{2}(56 \%), \mathrm{P}_{2} \times \mathrm{P}_{3}(56 \%), \mathrm{P}_{2} \times \mathrm{P}_{6}(52 \%), \mathrm{P}_{4} \times \mathrm{P}_{6}(52 \%), \mathrm{P}_{1} \times \mathrm{P}_{5}$ (48\%), $\mathrm{P}_{1} \times \mathrm{P}_{6}(48 \%), \mathrm{P}_{1} \times \mathrm{P}_{7}(48 \%), \mathrm{P}_{2} \times \mathrm{P}_{4}(48 \%)$ and $\mathrm{P}_{4} \times \mathrm{P}_{5}(48 \%)$.

Table 4. Success in crossing between different parents of lemon.

\begin{tabular}{|c|c|c|c|}
\hline Cross combination & $\begin{array}{l}\text { No. of successful } \\
\text { crosses }\end{array}$ & $\begin{array}{c}\text { Percentage of fruit } \\
\text { set }\end{array}$ & Seeds/fruit \\
\hline$\overline{\mathrm{P}_{1} \times \mathrm{P}_{2}}$ & 14 & 56 & $11-21$ \\
\hline $\mathrm{P}_{1} \times \mathrm{P}_{3}$ & 10 & 40 & $13-17$ \\
\hline $\mathrm{P}_{1} \times \mathrm{P}_{4}$ & 9 & 36 & $19-23$ \\
\hline $\mathrm{P}_{1} \times \mathrm{P}_{5}$ & 12 & 48 & $13-20$ \\
\hline $\mathrm{P}_{1} \times \mathrm{P}_{6}$ & 12 & 48 & $16-22$ \\
\hline $\mathrm{P}_{1} \times \mathrm{P}_{7}$ & 12 & 48 & $11-18$ \\
\hline $\mathrm{P}_{2} \times \mathrm{P}_{3}$ & 14 & 56 & $21-33$ \\
\hline $\mathrm{P}_{2} \times \mathrm{P}_{4}$ & 12 & 48 & $20-29$ \\
\hline $\mathrm{P}_{2} \times \mathrm{P}_{5}$ & 10 & 40 & $11-16$ \\
\hline $\mathrm{P}_{2} \times \mathrm{P}_{6}$ & 13 & 52 & $7-17$ \\
\hline $\mathrm{P}_{2} \times \mathrm{P}_{7}$ & 10 & 40 & $5-11$ \\
\hline $\mathrm{P}_{3} \times \mathrm{P}_{4}$ & 11 & 44 & $7-12$ \\
\hline $\mathrm{P}_{3} \times \mathrm{P}_{5}$ & 5 & 20 & $4-8$ \\
\hline $\mathrm{P}_{3} \times \mathrm{P}_{6}$ & 11 & 44 & $9-15$ \\
\hline $\mathrm{P}_{3} \times \mathrm{P}_{7}$ & 9 & 36 & $3-7$ \\
\hline $\mathrm{P}_{4} \times \mathrm{P}_{5}$ & 12 & 48 & $13-17$ \\
\hline $\mathrm{P}_{4} \times \mathrm{P}_{6}$ & 13 & 52 & $14-26$ \\
\hline $\mathrm{P}_{4} \times \mathrm{P}_{7}$ & 10 & 40 & $9-18$ \\
\hline $\mathrm{P}_{5} \times \mathrm{P}_{6}$ & 9 & 36 & $7-13$ \\
\hline $\mathrm{P}_{5} \times \mathrm{P}_{7}$ & 8 & 32 & $8-13$ \\
\hline $\mathrm{P}_{6} \times \mathrm{P}_{7}$ & 10 & 40 & $9-20$ \\
\hline
\end{tabular}


These combinations also produced more seeds compared to other cross combinations (Table 4); it might be due to higher cross compatibility of these parents. The lowest percentage of fruit setting was recorded in cross $\mathrm{P}_{3} \times \mathrm{P}_{5}$ (20\%). The rest of the crosses exhibited moderate to lower percentage of fruit setting as well as seed setting. The maximum number of seeds was produced from $\mathrm{P}_{2} \times \mathrm{P}_{3}$ (21-33), while the lowest was in $\mathrm{P}_{3} \times \mathrm{P}_{7}$ (Table 4).

The low fruit setting seemed to be due to cross incompatibility among the parents. It might be due to genetical factor. Khodzhaeva (1988) found selfsterility in Central Asia lemon and observed some cultivars cropped well when cross-pollinated with each other. In sweet orange, Domingues and Tulmann (1999) observed 68\% varieties set fruit under free pollination, $15 \%$ under self pollination and $35 \%$ by cross pollination which are in line with the present results.

\section{Conclusion}

The study helped in finding out some compatible parents. The results may help the breeders to design breeding programme with lemon for proper utilization of genetic resources. To achieve precise information, large number of genotypes should be included in a crossing programme. However, the performance of hybrids obtained from different cross combinations need to be evaluated by comparing with their parents through further field trials.

\section{Acknowledgement}

The author is grateful to USDA funded project (Project No. 99/21/USDA: Grant \# BGARS-108) for providing materials and necessary experimental facilities to conduct this research.

\section{References}

Barrett, H.C. 1985. Hybridization of Citrus and related genera. Fruit Var. J. 39 (2): 11-16.

Domingues, E.T. and N.A. Tulmann. 1999. Influence of pollination and floral morphology on fruit setting in sweet orange varieties. Scientia Agricola 56 (1): 163170 [Cited from CAB Abst., Vol. CIAC, 1998-2000].

Khodzhaeva, R.Z. 1988. Lemon fruit set in protected cultivation. Sadovodstvo: Ainogradarstvo 4: 29-30 [Cited from CAB Abst., Vol. CIAC, 1987-1989].

Luro, F., F. Maddy, C. Jacquemond, Y. Froelicher, R. Morillon, D. Rist and P. Ollitrault. 2004. Identification and evaluation of diplogyny in Clementine (Citrus clementina) for use in breeding. Acta Hort. 663(2): 84 1-847.

Nath, J.C. 1999. Studies on floral biology of Assam lemon (Citrus limon Burm). Annals Agric. Res. 20(2): 238-239. 
Soost, R.K. and J.W. Cameron. 1975. Citrus. In "Advances in Fruit Breeding" (J. Janick and J.N. Moore, eds.). Purdue Univ. Press. West Lafayette, Indiana. pp. 507-540.

Vardi, A., H. Neumann, S.A. Frydman, Y. Yaniv, R.P. Spiegel, R. Goren and E. E. Goldschmidt (ed.). 2000. Tentative model on the inheritance of juvenility, selfincompatibility and parthenocarpy. Acta Hort. 535: 199-205.

Yamamoto, M. and S. Tominaga. 2002. Relationship between seedlessness of Keraji (Citrus keraji hort. ex. Tanaka) and female sterility and self-incompatibility. $J$. Japanese. Soc. Hort. Sci. 72(2): 183-186. 